Note

\title{
Synthesis and structural characterization of dimolybdenum(IV) and molybdenum(VI) complexes with trisbenzenethiolatophosphine ligands
}

\author{
Hua-Fen Hsu ${ }^{\text {a,* }}$, Wan-Yu Peng ${ }^{a}$, Zung-Ying $\mathrm{Li}^{\mathrm{a}}$, Ru-Rong Wu ${ }^{\mathrm{a}}$, Ju-Hsiou Liao ${ }^{\mathrm{b}}$, \\ Yu Wang ${ }^{c}$, Yi-Hung Liu ${ }^{c}$, Minghuey Shieh ${ }^{d}$, Ting-Shen Kuo ${ }^{d}$ \\ a Department of Chemistry, National Cheng Kung University, No1, Ta-Hsueh Road, Tainan 701, Taiwan \\ ${ }^{\mathrm{b}}$ Department of Chemistry, National Chung Cheng University, Chia-Yi, Taiwan \\ ${ }^{c}$ Department of Chemistry, National Taiwan University, Taipei 117, Taiwan \\ d Department of Chemistry, National Taiwan Normal University, Taipei 116, Taiwan
}

Received 21 November 2004; accepted 28 December 2004

Available online 7 February 2005

\begin{abstract}
The synthesis and crystal structures of two high valent molybdenum complexes containing trisbenzenethiolatophosphine ligands, $\left[\mathrm{Mo}_{2}(\mathrm{PS} 3)_{2}(\mathrm{PS} 3 \mathrm{H})\right] \quad(1)$ and $\left[\mathrm{Mo}\left(\mathrm{PS}^{\prime \prime}\right)_{2}\right] \quad(2)$, where $\mathrm{PS} 3=\left[\mathrm{P}\left(\mathrm{C}_{6} \mathrm{H}_{4}-2-\mathrm{S}\right)_{3}\right]^{3-}, \quad \mathrm{PS} 3 \mathrm{H}=\left[\mathrm{P}\left(\mathrm{C}_{6} \mathrm{H}_{4}-2-\mathrm{S}\right)_{2}\left(\mathrm{C}_{6} \mathrm{H}_{4}-2-\mathrm{SH}\right)\right]^{2-}, \quad$ and $\mathrm{PS}^{\prime \prime}=\left[\mathrm{P}\left(\mathrm{C}_{6} \mathrm{H}_{3}-3-\mathrm{Me}_{3} \mathrm{Si}-2-\mathrm{S}\right)_{3}\right]^{3-}$, are described. Compound 1 is a dimeric $\mathrm{Mo}(\mathrm{IV})$ species containing three PS3 ligands with an uncoordinated thiol group. An intramolecular hydrogen bonding $\mathrm{S}-\mathrm{H} \cdots \mathrm{S}$ was found in the structure. Two molybdenum ions are bridged by three thiolates. The geometry can be described as two pentagonal bipyramids sharing a triangle face formed by three bridging S atoms. Compound $\mathbf{2}$ is a Mo(VI) species binding with two tetradentate PS3" ligands. The eight-coordinate molybdenum center adopts a dodecahedral geometry.
\end{abstract}

(c) 2005 Elsevier B.V. All rights reserved.

Keywords: Molybdenum complexes; S-donor ligand; Eight-coordinate; Dodecahedral geometry; ${ }^{31} \mathrm{P}$ NMR

\section{Introduction}

To continue our efforts on studying the chemistry of thiofunctional metal complexes relevant to biological processes, we have extended our interest to molybdenum chemistry [1]. The chemistry of molybdenum-sulfur complexes has drawn much attention due to its biological significance [2-4]. Two classes of enzymes have been found to contain molybdenum. They are nitrogenase and oxotransferase. The former catalyzes the reduction of dinitrogen and the latter plays an important role for

\footnotetext{
* Corresponding author. Tel.: +88662757575; fax: +88662740552 .

E-mail address: konopka@mail.ncku.edu.tw (H.-F. Hsu).
}

oxygen atom transfer to or from a substrate $[5,6]$. The molybdenum centers in both enzymes have S-rich coordination environments. To elucidate how molybdenum sites in these two enzymes participate in these relevant biological reactions, it is advantageous to explore the basic coordination chemistry of molybdenum, particularly, in a ligation environment similar to the enzymes. To this end, we utilize trisbenzenethiolatophosphines, PS3 and PS3", as title ligands which were first developed by Zubieta's laboratory and have been investigated in other metal chemistry [1,7-16]. In the reaction of molybdenum with these tetradentate ligands, two high valent molybdenum complexes, $\left[\mathrm{Mo}_{2}(\mathrm{PS} 3)_{2}(\mathrm{PS} 3 \mathrm{H})\right]$ (1) and $\left[\mathrm{Mo}\left(\mathrm{PS}^{\prime \prime}\right)_{2}\right](2)$, were obtained. We detail our results here. 


\section{Experimental}

\subsection{General considerations}

Manipulations were performed under a nitrogen atmosphere by standard Schlenk techniques or in a $\mathrm{N}_{2}$-filled glove box unless it is mentioned. $\mathrm{MoCl}_{3}(\mathrm{THF})_{3}, \quad[\mathrm{PS} 3] \mathrm{H}_{3}, \quad$ and $\left[\mathrm{PS}^{\prime \prime}\right] \mathrm{H}_{3}$, where $[\mathrm{PS} 3] \mathrm{H}_{3}=\mathrm{P}\left(\mathrm{C}_{6} \mathrm{H}_{4}-2-\mathrm{SH}\right)_{3}$ and $\left[\mathrm{PS}^{\prime \prime}\right] \mathrm{H}_{3}=\mathrm{P}\left(\mathrm{C}_{6} \mathrm{H}_{3}-3-\right.$ $\left.\mathrm{Me}_{3} \mathrm{Si}-2-\mathrm{SH}\right)_{3}$, were synthesized according to the literature procedures [17-19]. Solvents were dried, distilled and degassed using standard techniques. Otherwise, all starting materials were obtained commercially and used without further purification. Electronic spectra were recorded at the range of $300-1100 \mathrm{~nm}$ on Hewlett-Packard 8453 spectrophotometer. ${ }^{1} \mathrm{H}$ and ${ }^{31} \mathrm{P}-\left\{{ }^{1} \mathrm{H}\right\}$ NMR measurements were performed on a BRUKER AMX400 at ambient temperature. The resonance positions are reported with positive shifts downfield of $\mathrm{SiMe}_{4}$ as calculated from the residual solvent peaks $\left({ }^{1} \mathrm{H}\right)$ or downfield of external $85 \% \mathrm{H}_{3} \mathrm{PO}_{4}\left({ }^{31} \mathrm{P}\right)$.

\subsection{The synthesis of $\left[\mathrm{Mo}_{2}(\mathrm{PS} 3)_{2}(\mathrm{PS} 3 \mathrm{H})\right](\mathbf{1})$}

A $\mathrm{CH}_{2} \mathrm{Cl}_{2}$ solution of $\mathrm{MoCl}_{3}(\mathrm{THF})_{3} \quad(0.08 \mathrm{~g}$, $0.19 \mathrm{mmol})$ was added to the mixture of $[\mathrm{PS} 3] \mathrm{H}_{3}$ $(0.1 \mathrm{~g}, 0.28 \mathrm{mmol})$ and sodium methoxide $(0.047 \mathrm{~g}$, $0.87 \mathrm{mmol}$ ) in $\mathrm{CH}_{2} \mathrm{Cl}_{2}$ to generate a bluish-purple solution. The solution was filtered and the filtrate was layered with ether. After 1 day, the purple crystalline solid was precipitated from the solution. The solid was recrystallized from $\mathrm{CH}_{2} \mathrm{Cl}_{2}$ and ether to give $0.06 \mathrm{~g}$ $(0.048 \mathrm{~mol})$ of 1 with the yield of $51 \%$. Anal. Calc. for $\mathrm{C}_{54} \mathrm{H}_{37} \mathrm{P}_{3} \mathrm{~S}_{9} \mathrm{Mo}_{2}: \mathrm{C}, 51.47 ; \mathrm{H}, 3.02 ; \mathrm{S}, 22.87$. Found: C, 49.70; H, 3.12; S, 21.81. ${ }^{31} \mathrm{P}-\left\{{ }^{1} \mathrm{H}\right\}$ NMR $\left(\mathrm{CH}_{2} \mathrm{Cl}_{2}\right)$ : $\delta \quad 116.8 \quad\left(\mathrm{t}, \quad J_{\mathrm{P} 3-\mathrm{P} 1}=10.04 \mathrm{~Hz}, \quad J_{\mathrm{P} 3-\mathrm{P} 2}=10.04 \mathrm{~Hz}\right.$, $\left.P\left(\mathrm{C}_{6} \mathrm{H}_{4}-2-\mathrm{S}\right)_{3}\right), \quad 109.4 \quad\left(\mathrm{q}, \quad J_{\mathrm{P} 2-\mathrm{P} 3}=10.04 \mathrm{~Hz}, \quad J_{\mathrm{P} 2-}\right.$ $\left.{ }_{\mathrm{P} 1}=23.76 \mathrm{~Hz}, P\left(\mu-\mathrm{C}_{6} \mathrm{H}_{4}-2-\mathrm{S}\right)_{2}\left(\mathrm{C}_{6} \mathrm{H}_{4}-2-\mathrm{S}\right)\right)$ and $64.0(\mathrm{q}$, $J_{\mathrm{P} 1-\mathrm{P} 3}=10.04 \mathrm{~Hz}, \quad J_{\mathrm{P} 1-\mathrm{P} 2}=23.76 \mathrm{~Hz}, \quad P\left(\mu-\mathrm{C}_{6} \mathrm{H}_{4}-2-\right.$ S) $\left.\left(\mathrm{C}_{6} \mathrm{H}_{4}-2-\mathrm{S}\right)\left(\mathrm{C}_{6} \mathrm{H}_{4}-2-\mathrm{SH}\right)\right)$. UV-vis in $\mathrm{CH}_{2} \mathrm{Cl}_{2}(\lambda, \mathrm{nm}$; $\left.\varepsilon, \mathrm{M}^{-1} \mathrm{~cm}^{-1}\right): 535\left(2.3 \times 10^{4}\right), 698\left(1.3 \times 10^{4}\right)$.

\subsection{The synthesis of $\left[\mathrm{Mo}\left(\mathrm{PS}^{\prime \prime}\right)_{2}\right]$ (2)}

A THF solution of $\quad \mathrm{MoCl}_{3}(\mathrm{THF})_{3} \quad(0.075 \mathrm{~g}$ $0.17 \mathrm{mmol})$ was added to the mixture of $\left[\mathrm{PS}^{\prime \prime}\right] \mathrm{H}_{3}$ $(0.2 \mathrm{~g}, 0.35 \mathrm{mmol})$ and sodium methoxide $(0.06 \mathrm{~g}$, $1.1 \mathrm{mmol}$ ) in THF to generate a purple solution. The color of the solution changed to olive green after exposure to the air for $30 \mathrm{~s}$. THF was removed and the residue was redissolved in methanol followed by filtration. The brown crystalline solid was obtained after the solvent evaporated from the filtrate. The solid was washed with methanol and dried in vaccum to give $0.15 \mathrm{~g}$ $(0.12 \mathrm{mmol})$ of 2 with $70 \%$ yield. Anal. Calc. for $\mathrm{C}_{54} \mathrm{H}_{72} \mathrm{P}_{2} \mathrm{~S}_{6} \mathrm{Si}_{6} \mathrm{Mo}$ : C, 52.34; H, 5.80; S, 15.50. Found:
C, 51.17; H, 5.86; S, 15.30. ${ }^{31} \mathrm{P}-\left\{{ }^{1} \mathrm{H}\right\}$ NMR $\left(\mathrm{CDCl}_{3}\right)$ : $\delta$ 114.7(s). ${ }^{1} \mathrm{H}$ NMR $\left(\mathrm{CDCl}_{3}\right): \delta 7.1,7.4,7.8(\mathrm{~m}, 9 \mathrm{H}$, $\left.\mathrm{P}\left(\mathrm{C}_{6} H_{3}-3-\left(\mathrm{CH}_{3}\right)_{3} \mathrm{Si}-2-\mathrm{S}\right)_{3}\right), \quad \delta \quad 0 \quad\left(\mathrm{~s}, 27 \mathrm{H}, \quad \mathrm{P}\left(\mathrm{C}_{6} \mathrm{H}_{3}-3-\right.\right.$ $\left.\left.\left(\mathrm{CH}_{3}\right)_{3} \mathrm{Si}-2-\mathrm{S}\right)_{3}\right)$. UV-vis in $\mathrm{CH}_{2} \mathrm{Cl}_{2}(\lambda, \mathrm{nm} ; \varepsilon$, $\left.\mathrm{M}^{-1} \mathrm{~cm}^{-1}\right): 830\left(9.9 \times 10^{3}\right)$.

\subsection{X-ray analysis of the structures}

Crystallographic data and refinement parameters for compounds $\mathbf{1}$ and $\mathbf{2}$ are summarized in Table 1. The selected bond distances and angles are listed in Tables 2 and 3. Each crystal was mounted on a glass fiber and quickly coated in epoxy resin. Diffraction measurements were carried out at 100(2) K for $\mathbf{1}$ and 295(2) K for $\mathbf{2}$ on a Bruker SMART 1000 CCD diffractometer with graphite-monochromated Mo $\mathrm{K} \alpha$ radiation $(\lambda=0.7107 \AA)$. The structure was determined by SHELXTL program [20]. ASADABS absorption correction was made [21]. All the non-hydrogen atoms were refined with anisotropic displacement factors. All the hydrogen atoms are calculated by using the riding model.

\section{Results and discussion}

\section{1. $\left[\mathrm{Mo}_{2}(\mathrm{PS} 3)_{2}(\mathrm{PS} 3 \mathrm{H})\right](1)$}

Adding 3 equivalents of $\mathrm{PS} 3$ in $\mathrm{CH}_{2} \mathrm{Cl}_{2}$ to 2 equivalents of $\mathrm{MoCl}_{3}(\mathrm{THF})_{3}$ in $\mathrm{CH}_{2} \mathrm{Cl}_{2}$ generated a bluishpurple solution. After layering ether to the reaction

Table 1

Crystallographic data for compounds $\mathbf{1}$ and $\mathbf{2}$

\begin{tabular}{|c|c|c|}
\hline & $\mathbf{1} \cdot 4 \mathrm{CH}_{2} \mathrm{Cl}_{2} \cdot \mathrm{H}_{2} \mathrm{O}$ & 2 \\
\hline Formula & $\mathrm{C}_{58} \mathrm{H}_{47} \mathrm{Cl}_{8} \mathrm{Mo}_{2} \mathrm{OP}_{3} \mathrm{~S}_{9}$ & $\mathrm{C}_{54} \mathrm{H}_{72} \mathrm{MoP}_{2} \mathrm{~S}_{6} \mathrm{Si}_{6}$ \\
\hline$M\left(\mathrm{~g} \mathrm{~mol}^{-1}\right)$ & 1616.89 & 1239.90 \\
\hline$T(\mathrm{~K})$ & $100(2)$ & $295(2)$ \\
\hline Crystal system & monoclinic & monoclinic \\
\hline Space group & $P 2{ }_{1} / a$ & $P 2_{1} / n$ \\
\hline$a(\AA)$ & $19.7240(7)$ & $22.0640(5)$ \\
\hline$b(\AA)$ & $13.4200(4)$ & $12.3000(3)$ \\
\hline$c(\AA)$ & $24.2980(8)$ & $25.2240(8)$ \\
\hline$\alpha\left({ }^{\circ}\right)$ & 90 & 90 \\
\hline$\beta\left({ }^{\circ}\right)$ & $96.771(1)$ & $107.612(1)$ \\
\hline$\gamma\left({ }^{\circ}\right)$ & 90 & 90 \\
\hline$V\left(\AA^{3}\right)$ & $6386.7(4)$ & $6524.6(3)$ \\
\hline$Z$ & 4 & 4 \\
\hline$D_{\text {calc }}\left(\mathrm{g} \mathrm{cm}^{-1}\right)$ & 1.682 & 1.262 \\
\hline$\mu\left(\mathrm{Mo} \mathrm{K}_{\alpha}\right)\left(\mathrm{mm}^{-1}\right)$ & 1.138 & 0.585 \\
\hline$F(000)$ & 3248 & 2592 \\
\hline Collected data & 36216 & 35700 \\
\hline Unique data $\left(R_{\text {int }}\right)$ & $10744(0.0661)$ & $11441(0.1465)$ \\
\hline Refined parameters & 702 & 623 \\
\hline$R_{1}{ }^{\mathrm{a}}[I>2 \sigma(I)]$ & 0.0798 & 0.0566 \\
\hline$w R_{2}^{\mathrm{b}}[I>2 \sigma(I)]$ & 0.2049 & 0.0944 \\
\hline $\mathrm{GOF}^{\mathrm{c}}$ & 1.115 & 0.963 \\
\hline
\end{tabular}

a $R_{1}=\sum|| F_{\mathrm{o}}|-| F_{\mathrm{c}}|| / \sum\left|F_{\mathrm{o}}\right|$

b $w R_{2}=\left\{\sum\left[w\left(F_{\mathrm{o}}^{2}-F_{\mathrm{c}}^{2}\right)^{2}\right] / \sum\left[w\left(F_{\mathrm{o}}^{2}\right)^{2}\right]\right\}^{1 / 2}$.

c Goodness-of-fit on $F^{2}$. 
Table 2

Selected bond lengths $(\AA)$ and angles $\left(^{\circ}\right)$ with standard uncertainties for $\left[\mathrm{Mo}_{2}(\mathrm{PS} 3)_{2}(\mathrm{PS} 3 \mathrm{H})\right](\mathbf{1})$

\begin{tabular}{llll}
\hline $\mathrm{Mo}(1)-\mathrm{Mo}(2)$ & $2.7187(10)$ & $\mathrm{Mo}(1)-\mathrm{S}(3)$ & $2.458(2)$ \\
$\mathrm{Mo}(1)-\mathrm{P}(1)$ & $2.465(2)$ & $\mathrm{Mo}(1)-\mathrm{S}(4)$ & $2.501(2)$ \\
$\mathrm{Mo}(1)-\mathrm{P}(2)$ & $2.459(2)$ & $\mathrm{Mo}(1)-\mathrm{S}(5)$ & $2.528(2)$ \\
$\mathrm{Mo}(1)-\mathrm{S}(2)$ & $2.480(2)$ & $\mathrm{Mo}(1)-\mathrm{S}(6)$ & $2.406(2)$ \\
$\mathrm{Mo}(2)-\mathrm{S}(3)$ & $2.584(2)$ & $\mathrm{Mo}(2)-\mathrm{S}(8)$ & $2.452(2)$ \\
$\mathrm{Mo}(2)-\mathrm{S}(4)$ & $2.516(2)$ & $\mathrm{Mo}(2)-\mathrm{S}(9)$ & $2.483(2)$ \\
$\mathrm{Mo}(2)-\mathrm{S}(6)$ & $2.494(2)$ & $\mathrm{Mo}(2)-\mathrm{P}(3)$ & $2.464(2)$ \\
$\mathrm{Mo}(2)-\mathrm{S}(7)$ & $2.425(2)$ & & \\
$\mathrm{Mo}(1)-\mathrm{S}(3)-\mathrm{Mo}(2)$ & $65.20(6)$ & $\mathrm{S}(3)-\mathrm{Mo}(2)-\mathrm{S}(9)$ & $69.40(7)$ \\
$\mathrm{Mo}(1)-\mathrm{S}(3)-\mathrm{Mo}(2)$ & $65.20(6)$ & $\mathrm{S}(3)-\mathrm{Mo}(2)-\mathrm{S}(9)$ & $69.40(7)$ \\
$\mathrm{Mo}(1)-\mathrm{S}(4)-\mathrm{Mo}(2)$ & $65.62(6)$ & $\mathrm{S}(9)-\mathrm{Mo}(2)-\mathrm{P}(3)$ & $70.69(7)$ \\
$\mathrm{Mo}(1)-\mathrm{S}(6)-\mathrm{Mo}(2)$ & $67.37(6)$ & $\mathrm{P}(2)-\mathrm{Mo}(1)-\mathrm{S}(5)$ & $71.83(8)$ \\
$\mathrm{S}(6)-\mathrm{Mo}(2)-\mathrm{S}(8)$ & $166.58(8)$ & $\mathrm{S}(5)-\mathrm{Mo}(1)-\mathrm{S}(2)$ & $70.63(8)$ \\
$\mathrm{S}(6)-\mathrm{Mo}(1)-\mathrm{P}(1)$ & $163.50(9)$ & $\mathrm{S}(2)-\mathrm{Mo}(1)-\mathrm{S}(3)$ & $76.75(8)$ \\
$\mathrm{P}(3)-\mathrm{Mo}(2)-\mathrm{S}(7)$ & $75.78(8)$ & $\mathrm{S}(3)-\mathrm{Mo}(1)-\mathrm{S}(4)$ & $68.68(7)$ \\
$\mathrm{S}(7)-\mathrm{Mo}(2)-\mathrm{S}(4)$ & $78.25(7)$ & $\mathrm{S}(4)-\mathrm{Mo}(1)-\mathrm{P}(2)$ & $75.84(7)$ \\
$\mathrm{S}(4)-\mathrm{Mo}(2)-\mathrm{S}(3)$ & $66.51(7)$ & & \\
\hline
\end{tabular}

Table 3

Selected bond lengths $(\AA)$ and angles $\left(^{\circ}\right)$ with standard uncertainties for $\left[\mathrm{Mo}\left(\mathrm{PS}^{\prime \prime}\right)_{2}\right](\mathbf{2})$

\begin{tabular}{llll}
\hline $\mathrm{Mo}(1)-\mathrm{P}(1)$ & $2.513(2)$ & $\mathrm{Mo}(1)-\mathrm{S}(3)$ & $2.471(2)$ \\
$\mathrm{Mo}(1)-\mathrm{P}(2)$ & $2.507(2)$ & $\mathrm{Mo}(1)-\mathrm{S}(4)$ & $2.429(2)$ \\
$\mathrm{Mo}(1)-\mathrm{S}(1)$ & $2.438(2)$ & $\mathrm{Mo}(1)-\mathrm{S}(5)$ & $2.6257(14)$ \\
$\mathrm{Mo}(1)-\mathrm{S}(2)$ & $2.616(2)$ & $\mathrm{Mo}(1)-\mathrm{S}(6)$ & $2.468(2)$ \\
$\mathrm{P}(1)-\mathrm{Mo}(1)-\mathrm{P}(2)$ & $141.35(6)$ & $\mathrm{P}(1)-\mathrm{Mo}(1)-\mathrm{S}(5)$ & $133.06(5)$ \\
$\mathrm{S}(1)-\mathrm{Mo}(1)-\mathrm{S}(6)$ & $149.67(5)$ & $\mathrm{S}(4)-\mathrm{Mo}(1)-\mathrm{S}(3)$ & $149.85(5)$ \\
$\mathrm{S}(4)-\mathrm{Mo}(1)-\mathrm{P}(1)$ & $131.95(5)$ & $\mathrm{S}(1)-\mathrm{Mo}(1)-\mathrm{P}(2)$ & $132.03(5)$ \\
$\mathrm{S}(3)-\mathrm{Mo}(1)-\mathrm{S}(2)$ & $141.29(5)$ & $\mathrm{P}(2)-\mathrm{Mo}(1)-\mathrm{S}(2)$ & $133.44(5)$ \\
$\mathrm{S}(5)-\mathrm{Mo}(1)-\mathrm{S}(6)$ & $141.42(5)$ & $\mathrm{S}(2)-\mathrm{Mo}(1)-\mathrm{S}(5)$ & $131.69(5)$ \\
$\mathrm{S}(4)-\mathrm{Mo}(1)-\mathrm{S}(1)$ & $103.53(6)$ & $\mathrm{S}(1)-\mathrm{Mo}(1)-\mathrm{S}(3)$ & $93.65(6)$ \\
$\mathrm{S}(1)-\mathrm{Mo}(1)-\mathrm{S}(2)$ & $83.23(5)$ & $\mathrm{S}(3)-\mathrm{Mo}(1)-\mathrm{S}(5)$ & $80.06(5)$ \\
$\mathrm{S}(4)-\mathrm{Mo}(1)-\mathrm{S}(6)$ & $92.63(6)$ & $\mathrm{S}(3)-\mathrm{Mo}(1)-\mathrm{S}(6)$ & $84.16(5)$ \\
$\mathrm{S}(2)-\mathrm{Mo}(1)-\mathrm{S}(6)$ & $79.95(5)$ & $\mathrm{S}(5)-\mathrm{Mo}(1)-\mathrm{S}(4)$ & $84.16(5)$ \\
$\mathrm{S}(4)-\mathrm{Mo}(1)-\mathrm{S}(2)$ & $75.01(5)$ & $\mathrm{P}(2)-\mathrm{Mo}(1)-\mathrm{S}(3)$ & $75.08(5)$ \\
$\mathrm{P}(2)-\mathrm{Mo}(1)-\mathrm{S}(6)$ & $76.67(5)$ & $\mathrm{P}(1)-\mathrm{Mo}(1)-\mathrm{S}(1)$ & $74.92(5)$ \\
$\mathrm{P}(1)-\mathrm{Mo}(1)-\mathrm{S}(6)$ & $75.19(5)$ & $\mathrm{P}(1)-\mathrm{Mo}(1)-\mathrm{S}(3)$ & $76.19(5)$ \\
$\mathrm{P}(1)-\mathrm{Mo}(1)-\mathrm{S}(2)$ & $65.71(5)$ & $\mathrm{S}(4)-\mathrm{Mo}(1)-\mathrm{S}(2)$ & $66.44(5)$ \\
$\mathrm{S}(1)-\mathrm{Mo}(1)-\mathrm{S}(5)$ & $66.83(5)$ & $\mathrm{P}(2)-\mathrm{Mo}(1)-\mathrm{S}(5)$ & $65.33(5)$ \\
\hline
\end{tabular}

mixture for a day, the purple crystalline solid of $\mathbf{1}$ was precipitated in the yield of $51 \%$. The formation of dimolybdenum(IV) complex from Mo(III) starting material indicates the involvement of oxidant in the reaction, presumably due to the diffusion of the air to the solution during crystallization. To test it, $5 \mathrm{~mL}$ of air was added to the reaction mixture of PS3 and $\mathrm{MoCl}_{3}(\mathrm{THF})_{3}$. The bluish-purple solution changed to purple immediately. Adding ether only produced $38 \%$ of $\mathbf{1}$, probably, due to the decomposition of the compound in the presence of excess air.

The structure of $\mathbf{1}$ analyzed by X-ray crystallography is shown in Fig. 1. It consists of two seven-coordinate molybdenum centers binding with three PS3 ligands, in which one of the thiolates is protonated and does not coordinate to metal. The electron density of the hydrogen atom in the pendant thiol group could not

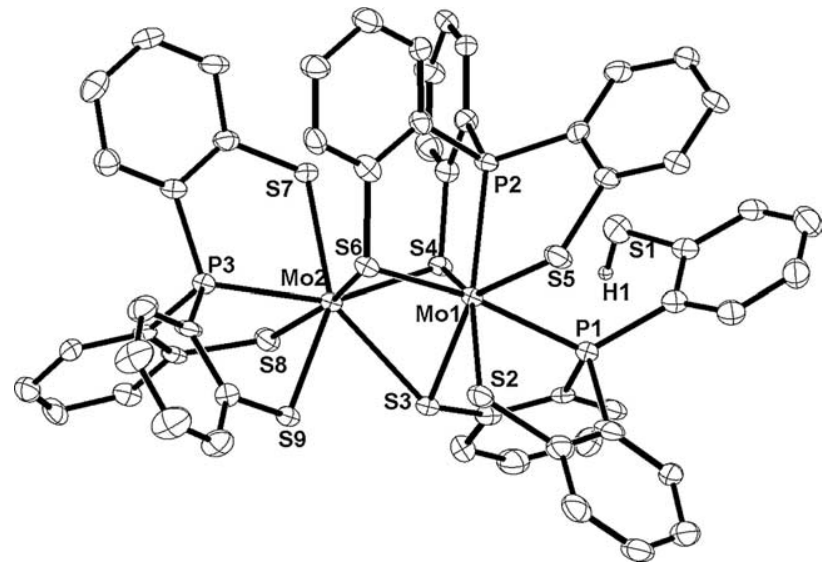

Fig. 1. The Ortep diagram of $\mathbf{1}$ shown with $35 \%$ thermal ellipsoids. $\mathrm{H}$ atoms except of $\mathrm{H} 1$ are omitted for clarity.

be identified from X-ray diffraction. However, the distance of $3.480 \AA$ between the uncoordinated $\mathrm{S}$ atom and one of the bridging S atoms (S4) is in the range of the hydrogen bonding interaction, supporting the presence of SH group in the structure. Other metal complexes of thiolatophosphine ligands containing uncoordinated thiol group have been reported in the literatures $[22,8,11,16]$. Among those, compound $\mathbf{1}$ is one of the rare examples structurally characterized by $\mathrm{X}$ ray crystallography [16].

The geometry of 1 could be viewed as two discrete pentagonal bipyramids that share a triangle face composed of three bridging thiolates (S3, S4, and S6 atoms). Two molybdenums have different coordination environment, $\mathrm{P}_{2} \mathrm{~S}_{5}$ for Mo1 and $\mathrm{P}_{1} \mathrm{~S}_{6}$ for Mo2. The Mo-S distances distribute in the range of 2.406(2)-2.584(2) $\AA$. The Mo2-( $\mu$-S6) bond is the shortest one, perhaps related to its trans position to Mo-P bond. The average of the bridging Mo-S distances (2.493 $\AA$ ) is comparable to that of the terminal Mo-S distances $(2.473 \AA$ ). Overall, the Mo-S bond distances in $\mathbf{1}$ are longer than those in four-coordinate and six-coordinate $\mathrm{Mo}(\mathrm{IV})$ thiolate complexes (2.24 $\AA$ for four-coordinate [23] and 2.35$2.36 \AA$ for six-coordinate $[22,24,25])$. The average of the Mo-P distance $(2.463 \AA)$ is similar to those of Mo(IV) thiolatophosphine complexes (2.46-2.52 $\mathrm{A}$ ) $[22,24]$. The Mo-Mo distance of $2.719(1) \AA$ is closed to those in dimolybdenum complexes that contain Mo-Mo single bond [26,27].

A ${ }^{31} \mathrm{P}-\left\{{ }^{1} \mathrm{H}\right\}$ NMR spectrum in $\mathrm{CH}_{2} \mathrm{Cl}_{2}$ shows three sets of resonances at $\delta 63.8,110.2$, and 116.6, indicating three non-equivalent phosphorus atoms present in $\mathbf{1}$ (Fig. 2). It is consistent with the X-ray structure that shows different chelating nature of three PS3 ligands. The resonance at 63.8 is much more upfield compared to the other two resonances and might be contributed to $\mathrm{P} 1$ atom that is connected to an uncoordinated thiol group and has a binding mode of $\mathrm{P}-\left(\mathrm{C}_{6} \mathrm{H}_{4}-2-\mathrm{S}\right)\left(\mu-\mathrm{C}_{6} \mathrm{H}_{4}-\right.$ 

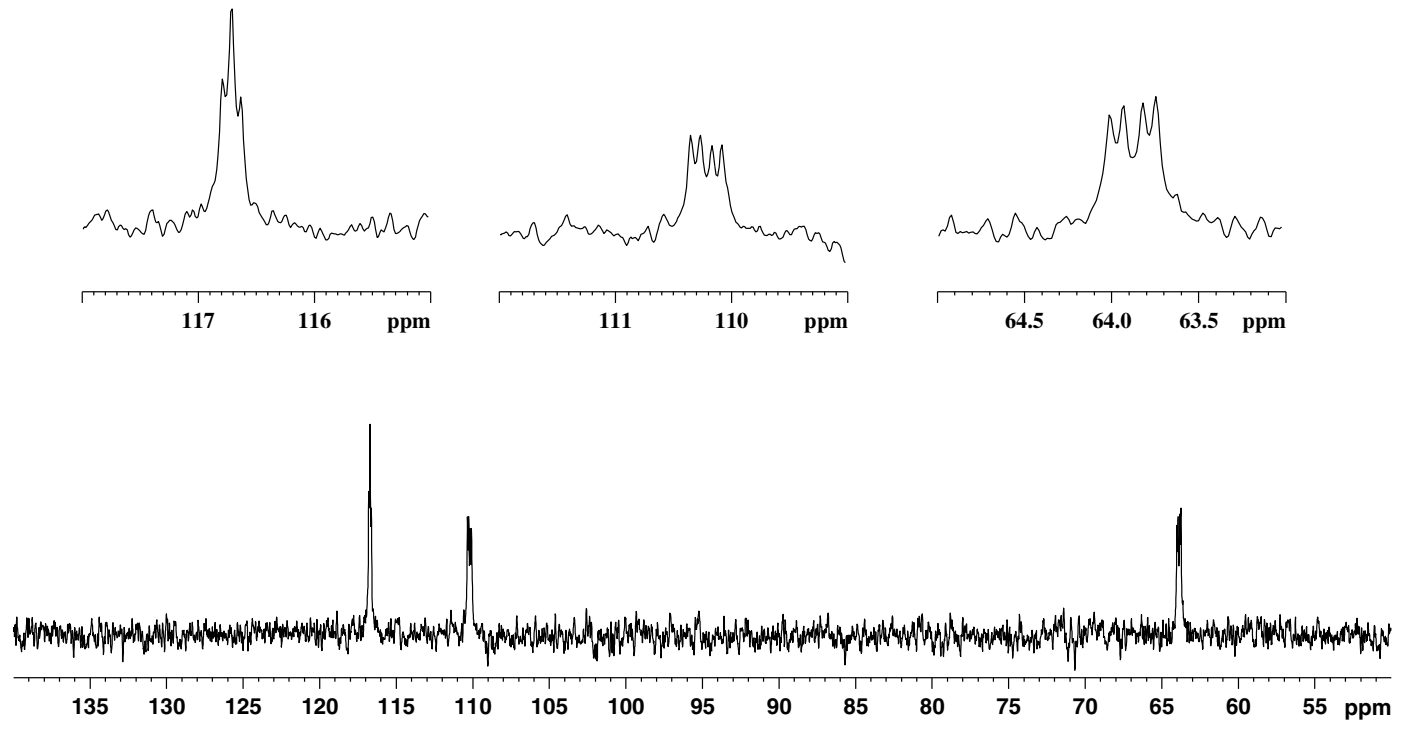

Fig. 2. ${ }^{31} \mathrm{P}-\left\{{ }^{1} \mathrm{H}\right\}$ NMR spectrum of $\mathbf{1}$.

2-S) $\left(\mathrm{C}_{6} \mathrm{H}_{4}-2-\mathrm{SH}\right)$. The resonance at 110.2 and 116.6 might be attributed to $\mathrm{P} 2$ and $\mathrm{P} 3$ atoms, respectively, which have distinguished binding modes, $\mathrm{P}-\left(\mathrm{C}_{6} \mathrm{H}_{4}-2-\right.$ $\mathrm{S})\left(\mu-\mathrm{C}_{6} \mathrm{H}_{4}-2-\mathrm{S}\right)_{2}$ for $\mathrm{P} 2$ atom and $\mathrm{P}-\left(\mathrm{C}_{6} \mathrm{H}_{4}-2-\mathrm{S}\right)_{3}$ for $\mathrm{P} 3$ atom. Three $\mathrm{P}$ atoms are coupled to each other with the coupling constants of $J(\mathrm{P} 1-\mathrm{P} 2)=23.76 \mathrm{~Hz}$, $J(\mathrm{P} 1-\mathrm{P} 3)=10.04 \mathrm{~Hz}$ and $J(\mathrm{P} 2-\mathrm{P} 3)=10.04 \mathrm{~Hz}$. Thus, the spectrum displays quartet, quartet and triplet splitting for the resonance at $63.8,110.2$, and 116.6 , respectively. The ${ }^{1} \mathrm{H}$ NMR spectrum shows resonance at $\delta$ 5.5-8.2, suggesting a diamagnetic species for 1 . The absence of resonance in paramagnetic regions agrees with the formula assignment that $\mathbf{1}$ is a dimeric Mo(IV) compound containing an unbound thiol group instead of a paramagnetic $\mathrm{Mo}(\mathrm{IV}) \mathrm{Mo}(\mathrm{V})$ species with an uncoordinated thiolate group. Attempts to locate the resonance of uncoordinated $\mathrm{S}-\mathrm{H}$ proton in ${ }^{1} \mathrm{H}$ NMR and $v(\mathrm{~S}-\mathrm{H})$ in the IR spectrum do not succeed. The failure might be resulted from the hydrogen bonding interaction of the hydrogen with the sulfur atom that leads to the broadness of signal in the spectra [8].

\section{2. $\left[\mathrm{Mo}\left(\mathrm{PS}^{\prime \prime}\right)_{2}\right](2)$}

Adding two equivalents of PS3" in THF to 1 equivalent of $\mathrm{MoCl}_{3}(\mathrm{THF})_{3}$ in THF generated a dark purple solution which changed to olive green after exposure to the air. THF was removed and the residue was dissolved in methanol. The solution was filtered and the brown crystalline solid of $\mathbf{2}$ ( $70 \%$ yield) was produced after methanol evaporated in the air.

The structure of $\mathbf{2}$ was characterized by X-ray crystallography and its ORTEP picture is shown in Fig. 3. The molybdenum(VI) center adopts a dodecahedral geometry by binding to two phosphorus and six sulfur atoms

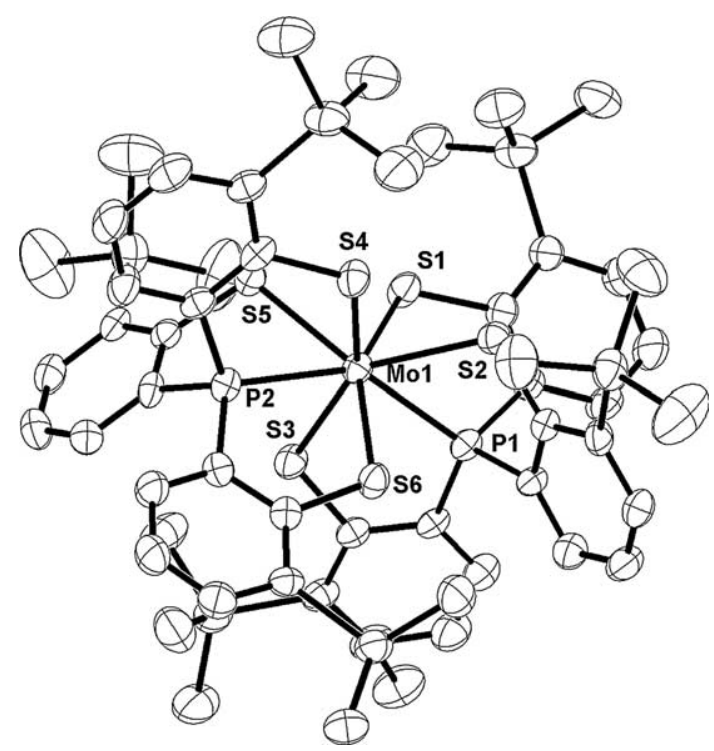

Fig. 3. The Ortep diagram of $\mathbf{2}$ shown with $35 \%$ thermal ellipsoids. $\mathrm{H}$ atoms are omitted for clarity.

of two PS3" ligands. S1, S5, S6, and P2 atoms form the same plane with the mean plane deviation of $0.023 \AA$. This plane is nearly perpendicular to the plane generated by P1, S3, S4, and S2 atoms with the mean plane deviation of $0.017 \AA$. The dihedral angle of $89.3^{\circ}$ between these two planes is closed to the ideal value of $90^{\circ}$ found in a regular dodecahedron [28,29]. (Fig. 4, left) Compounds with ideal dodecahedral geometries have been reported in the literatures [30-35]. Metal centers in those compounds are chelated by four bidentate ligands such as $\eta^{2}$-trithiocarbonate, dithiocarbamate or dithiobenzoate. Complex $\mathbf{2}$ is different from those examples in a way that the molybdenum center has a 

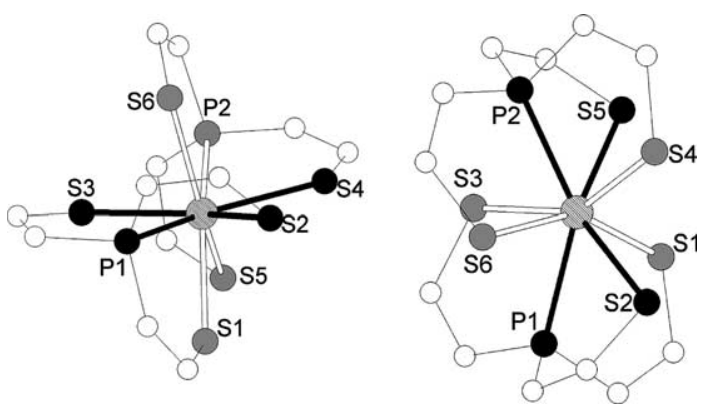

Fig. 4. The perspective drawings of 2 . Left drawing shows the view emphasizing two perpendicular planes in the dodecahedral structure (P1, S2, S3, S4 atoms form one plane and P2, S1, S5, S6 atoms form the other). Right drawing shows the view emphasizing two tetrahedrons in the dodecahedral structure (P1, P2, S2, S5 atoms form the elongated one and S1, S3, S4, S6 atoms form the collapsed one).

dodecahedral geometry by binding to two tetradentate ligands.

According to Holard and Silverstone [28], the overall dodecahedral geometry could be viewed as the overlap of an elongated tetrahedron and a collapsed tetrahedron. Such description for complex $\mathbf{2}$ is illustrated in Fig. 4. P1, P2, S2, S5 atoms form an elongated one and S1, S3, S4, S6 atoms produce a collapsed one. This arrangement is reflected on the two types of Mo-S bond distances observed in $\mathbf{2}$. The average distance of $\mathrm{Mo}-\mathrm{S}$ bonds in the elongated tetrahedron is $2.621 \AA, 0.17 \AA$ longer than that in the collapsed one $(2.452 \AA)$.

$\mathrm{A}^{31} \mathrm{P}-\left\{{ }^{1} \mathrm{H}\right\}$ NMR spectrum of 2 shows a single resonance at $\delta 114.7$, indicating two equivalent phosphorus atoms in the structure which agrees with the X-ray analysis. It is consistent with the ${ }^{1} \mathrm{H}$ NMR spectrum that displays three distinguished sets of resonances at $\delta 7.1,7.4$, and 7.8 contributed to the three hydrogen atoms in the phenyl rings of $\mathrm{PS} 3{ }^{\prime \prime}$ ligand.

\section{Conclusions}

Metal complexes ligated by thiolates are often not stable in high oxidation state due to the tendency of oxidizing thiolates to disulfide. The oxidation of Mo(III) binding to PS3 ligand offered a dimolybdenum(IV) complex (compound 1). The further oxidation resulted in the decomposition of the complex. In contrast, 2 represents a stable Mo(VI) complex that was also obtained from the oxidation of Mo(III) species. The trimethylsilyl substituents on the phenyl rings of PS3" in 2 might provide steric and electronic effects that prevent from the formation of the disulfides and assist in reaching a higher oxidation state. The geometries adopted by these two complexes are unique. It consists of two pentagonal bipyramids sharing with a triangle face in $\mathbf{1}$. In $\mathbf{2}$, it is considered as a dodecahedron. In addition, an uncoordinated thiol group was found forming an intramolecular hydrogen bond with a bridging thiolato group in the structure of compound $\mathbf{1}$.

\section{Supplementary material}

Crystallographic data for the structural analyses have been deposited with the Cambridge Crystallographic Data Center, CCDC-255990 (1) and CCDC-255991 (2). Copies of the data can be obtained free of charge on application to CCDC, 12 Union Road, Cambridge CB2 1EZ, UK (fax: +44-1223-336-033; email: deposit@ccdc.cam.ac.uk or http//www.ccdc.cam.ac.uk).

\section{Acknowledgments}

We thank the National Science Council in Taiwan (NSC 92-2113-M-006-018-) for generous support of this work.

\section{References}

[1] H.-F. Hsu, W.-C. Chu, C.-H. Hung, J.-H. Liao, Inorg. Chem. 42 (2003) 7369.

[2] F. Barriere, Coord. Chem. Rev. 236 (2003) 71.

[3] J.H. Enemark, J.J.A. Cooney, J.-J. Wang, R.H. Holm, Chem. Rev. 104 (2004) 1175.

[4] M. Hidai, S. Kuwata, Y. Mizobe, Acc. Chem. Res. 33 (2000) 46.

[5] J.B. Howard, D.C. Rees, Chem. Rev. 96 (1996) 2965.

[6] R. Hille, Chem. Rev. 96 (1996) 2757.

[7] N.d. Vries, J. Cook, A.G. Jones, A. Davison, Inorg. Chem. 30 (1991) 2662.

[8] J.R. Dilworth, Y. Zheng, J.R. Miller, J. Chem. Soc., Dalton Trans. (1992) 1757.

[9] J.D. Franolic, W.Y. Wang, M. Millar, J. Am. Chem. Soc. 114 (1992) 6587.

[10] J.D. Franolic, M. Millar, S.A. Koch, Inorg. Chem. 34 (1995) 1981.

[11] J.R. Dilworth, A.J. Hutson, J.S. Lewis, J.R. Miller, Y. Zheng, Q. Chen, J. Zubieta, J. Chem. Soc., Dalton Trans. (1996) 1093.

[12] D.H. Nguyen, H.-F. Hsu, M. Millar, S.A. Koch, J. Am. Chem. Soc. 118 (1996) 8963.

[13] H.-F. Hsu, S.A. Koch, C.V. Popescu, E. Münck, J. Am. Chem. Soc. 119 (1997) 8371.

[14] J.D. Niemoth-Anderson, K.A.F. Clark, T.A. George, C.R. Ross II, J. Am. Chem. Soc. 122 (2000) 3977.

[15] K.A.F. Clark, T.A. George, T.J. Brett, C.R. Ross II, R.K. Shoemaker, Inorg. Chem. 39 (2000) 2252.

[16] C.-M. Lee, C.-H. Chen, S.-C. Ke, G.-H. Lee, W.-F. Liaw, J. Am. Chem. Soc. 126 (2004) 8406.

[17] E. Block, G. Ofori-Okai, J. Zubieta, J. Am. Chem. Soc. 111 (1989) 2327.

[18] J.R. Dilworth, R.L. Richards, Inorg. Synth. 20 (1980) 121.

[19] J.R. Dilworth, J. Zubieta, Inorg. Synth. 24 (1986) 193.

[20] G.M. Sheldrick, ShelXTL, Program for Crystal Structure Determination, Siemens Analytical X-ray Instruments Inc., Madison, WI, 1994.

[21] G.M. Sheldrick, Sadabs, Simens Area Detector Absorption Correction Program, University of Göttingen, Göttingen, Germany, 1996. 
[22] P.J. Blower, J.R. Dilworth, G.J. Leigh, B.D. Neaves, F.B. Normanton, J. Hutchinson, J. Chem. Soc., Dalton Trans. (1985) 2647.

[23] S. Otsuka, M. Kamata, K. Hirotsu, T. Higuchi, J. Am. Chem. Soc. 103 (1981) 3011.

[24] Y. Arikawa, H. Kawaguchi, K. Kashiwabara, K. Tatsumi, Inorg. Chem. 38 (1999) 4549.

[25] J. Hyde, L. Magin, J. Zubieta, J. Chem. Soc., Chem. Commun. (1980) 204.

[26] F.A. Cotton, M.W. Extine, R.H. Niswander, Inorg. Chem. 17 (1978) 692.

[27] F.A. Cotton, J. Less-Common Met. 54 (1977) 3.

[28] J.L. Hoard, J.V. Silverton, Inorg. Chem. 2 (1963) 235.
[29] S.J. Lippard, B.J. Russ, Inorg. Chem. 7 (1968) 1686.

[30] C. Simonnet-Jégat, E. Cadusseau, R. Dessapt, F. Sécheresse, Inorg. Chem. 38 (1999) 2335.

[31] H.H. Murray, L. Wei, S.E. Sherman, M.A. Greaney, K.A. Eriksen, B. Carstensen, T.R. Halbert, E.I. Stiefel, Inorg. Chem. 34 (1995) 841.

[32] D.F. Lewis, R.C. Fay, Inorg. Chem. 15 (1976) 2219.

[33] C.D. Garner, N.C. Howlader, F.E. Mabbs, A.T. McPhail, R.W. Miller, K.D. Onan, J. Chem. Soc., Dalton Trans. (1978) 1582.

[34] R.D. Bereman, D.M. Baird, C.T. Vance, J. Hutchinson, J. Zubieta, Inorg. Chem. 22 (1983) 2316.

[35] M. Bonamico, G. Dessy, V. Fares, L. Scaramuzza, J. Chem. Soc., Dalton Trans. (1975) 2079. 